\title{
USE OF SOME EGYPTIAN SEAWEED AS FOLIAR FERTILIZER FOR VICIA FABA L. \\ Radwa A. Khairy ${ }^{1}$, Islam M. El-Manawy ${ }^{2}$ and Mohamed A. El- Bramawy $^{3}$ \\ 1- Agriculture Analytical Laboratory Unit, Agric. Fac., Suez Canal Univ. 2- Botany Dept., Fac. of Science, Suez Canal Univ. 3- Agronomy Dept., Fac. of Agriculture, Suez Canal Univ.
}

\begin{abstract}
Three common marine algae, Enteromorpha intestinalis, Ulva lactuca and Sarconema filiformis were collected from Suez Canal at Ismailia and chosen to examine their effects as a foliar spray on the growth and yield of faba beans in the Experimental Farm, Fac. of Agric., Suez Canal Univ., Ismailia in November 2006. The aqueous algal extracts were sprayed at concentrations of $0.05,0.10$ and 0.15 ; each was sprayed four times throughout the vegetative growth period of the plant. The results confirmed that application of eco-friendly fertilizers, derived from marine algae, was effective in increasing the measurements of growth and yield parameters. At the end of the growing season, Vicia faba plants grown with the foliar seaweed application had produced 1.6 to 2.25 folds of the unfertilized controls with using E. intestinalis, 1.7 to 2.4 folds using $U$. lactuca and 2.5 to 5.6 folds with using S. filiformis. This production may be referred to the minerals, hormone-like substances, amino acids and vitamins in different algae. The present production of broad bean did not reach the Egyptian yield of feddan and this may be attributed to the low PNK in algae. The present study concluded that seaweed products should be boosted with additional supplement of NPK.
\end{abstract}

Keywords: Faba bean, Natural fertilizer, Seaweed fertilizer.

\section{Introduction}

The natural biological biofertilizer has been identified as the best alternative to the chemical fertilizers in order to improve the soil fertility and, consequently, increase the crop production in sustainable farming. However, the continuous and judicious use of the biofertilizer improves the physical and chemical properties of nearly all soil types, particularly those which are shallow, coarse texture, or poor organic matter (Aseri et al., 2008). In recent years, biofertilizers have emerged as an important component of the integrated nutrient supply system and hold a great promise to improve crop yields through environmentally better nutrient supplies. It is containing living cells of different types of microorganisms, which have an ability to convert nutritionally important elements from unavailable to available form through biological processes (Hegde et al., 1999 and Vessey, 2003).

Biofertilizers such as seaweeds have a multiple uses in agriculture and they could be considered as a source of natural organic, non-polluted and renewable fertilizer. Booth (1966) observed that the value of seaweeds as 
fertilizers was not only due to nitrogen, phosphorus and potash content, but also because of the presence of trace elements and metabolites. Liquid extracts obtained from seaweeds have recently gained importance as foliar sprays for several crops (Agenbag, 1989; Nelson and van Staden, 1984; Salah El Din $\boldsymbol{e t}$ al., 2008), because the extract contains growth promoting hormones (IAA and IBA), cytokinins, trace elements $(\mathrm{Fe}, \mathrm{Cu}, \mathrm{Zn}, \mathrm{Co}, \mathrm{Mo}$, and $\mathrm{Mn})$, vitamins and amino acids (Challen and Hemingway, 1965). Seaweed fertilizer was found to be superior to chemical fertilizer because of the high level of organic matter aids in retaining moisture and minerals in the upper soil level available to the roots (Cardozo et al., 2007). The effect of seaweed extract depends on the type of the crop, its stage and the composition as well as concentration of seaweed applied (Blunden and Guiry, 1991; Salah El Din et al., 2008). In biological agriculture, diluted seaweed extracts are applied with the aim of promoting growth, stress resistance; prevent pests and diseases, and improving the quality of the products (Sanker et al., 2001; Zodape, 2001; Malaguti et al., 2002; Arthur et. al., 2003).

In Egypt, seaweeds occur along coastlines of Red Sea and Mediterranean but little attention has been directed to use them as biofertilizers (e.g., El-Sheekh and El-Saied, 2000). The objective of this work was to explore the Egyptian seaweeds in preparing sprays that could be useful in promoting the growth characters and improving the quality of the Vicia faba L., one of the richest sources of protein, plays an important role in the socio-economic life of Egyptian populations.

\section{Materials and Methods}

\section{Collection of seaweeds}

Three seaweed species were used in the present study, Ulva lactuca (Linnaeus), Enteromorphra compressa (Linnaeus) Greville from Chlorophyta and Sarconema filiforme Rayss from Rhodophyta. They were collected from a concrete shore, a half meter below water mark, on the Suez Canal nearby Ismailia city. The collection was carried out during May, 2006 and June, 2007. Selection of these species was based on the common presence and whole year round availability in the considering area. Algal samples were hand picked and washed thoroughly with seawater to remove all the unwanted impurities, adhering sand particles and epiphytes. Thalli of each alga were quickly rinsed with the tap water for removing salts, dripped, quickly dried on blotting paper and weighed. The samples were air-dried in a dark room, grind, sieved to remove fine sand, reweighed, and packed in labeled nylon bags. Species identification was carried out according to Aleem (1993). 


\section{Preparation of seaweed extract}

A kilogram of each algal sample was soaked overnight in a liter of distilled water, then filter with a muslin cheesecloth tissue and freezed at $-20^{\circ} \mathrm{C}$. For use, the filtrate was milted and the concentration of the extract considered being $100 \%$. Of this extract, different concentrations of $5 \%, 10 \%$, and $15 \%$ ) were prepared using distilled water.

\section{Crop cultivar}

The cultivar of Vicia fabea L. was Nubaria-1, a Leguminosae plant, whereas selected from Giza Blanka cultivar. Seeds were received from the Agriculture Research Center, Food Legumes Research Section, Giza, Egypt.

\section{Experimental site and its characteristics}

The experimental site located located at $30^{\circ} 37^{\prime} 4.47^{\prime \prime} \mathrm{N}$ and $32^{\circ} 15^{\prime}$ 48.66"E, $15 \mathrm{~m}$ above sea level the Experimental Farm, Fac. of Agric., Suez Canal Univ., Ismailia, Egypt. The average high temperature of Ismailia region is $28.2^{\circ} \mathrm{C}$, while the average low temperature is $14.7^{\circ} \mathrm{C}$; the precipitation is $35 \mathrm{~mm}$. The $\mathrm{pH}$, texture, organic matter and available nutrients were first measured to characterize the soil fertility status and texture. The soil of the site was a sandy textured soil (94.5\% sand, $2.5 \%$ silt and $3.0 \%$ clay) with $\mathrm{pH}$ of 7.8 . The experimental soil contained available nitrogen $(\mathrm{N}), 3.15$ and $3.33 \mathrm{ppm}$; available phosphorus $(\mathrm{P})$, 1.81 and $1.84 \mathrm{ppm}$ and available potassium $(\mathrm{K}), 11.68$ and $11.76 \mathrm{ppm}$ for seasons 2006 and 2007, respectively.

\section{Experimental design}

Three concentrations of each alga $(0.05,0.10$ and 0.15$)$ were used, in addition to control. Each subplot (Experimental unite) had an area of $5.40 \mathrm{~m}^{2}$, with 4 ridges, $3 \mathrm{~m}$ long and $0.45 \mathrm{~m}$ width, with single seed per hill and a spacing of $20 \mathrm{~cm}$ between hills. The Nubaria-1 cultivar seeds were sowed in November 2006.

\section{Algal Foliar applications}

Four foliar applications of each concentration of the alga were applied at $30,51,72$ and 93 days from sowing. No manure, chemical fertilizers or pesticides were used during the period of study. All recommended practices for Faba bean production were applied at optimum level.

\section{Field data collection}

Data on vegetative, yield and quality characters of the experimental crops was gathered during growth period and at harvesting at two days before second, third and forth sprays. Plant height (in $\mathrm{cm}$ ), number of branches, number of leaves and date of the first flower emerge were recorded just before every spray with 
algal extract. At harvesting of faba, number of pods per plant, shedding rate, and weight of 100 seeds $(\mathrm{gm})$, seed yield per plant (gm) were measured and the seed yield per plot $(\mathrm{kg})$ was then estimated.

\section{Laboratory data collection and analysis}

Major (N, P, K) and minor ( $\mathrm{Ca}, \mathrm{Fe}, \mathrm{Mn}, \mathrm{Zn}$ and $\mathrm{Mg}$ ) nutrients were measured in dried algae at Agriculture Analytical Laboratory Unit in Agric. Fac., Suez Canal University. While vitamins (A and C) and hormones (gibberellins, indole acetic acid, cytokinins and abscisic acid) were measured in fresh algae at the Central Lab of Agric. Fac. Centre, Cairo University. Moisture content, ash content, total carbohydrates (de Pádua et al., 2004), total proteins, lipids, and crude fibers were estimated as described in AOAC (1990).

\section{Statistical Analysas}

Data were analysed using an analysis of variance of a split-plot design, with treatments (alga) as the main plot, concentration as sub-plot as well as replicates as blocks. Statistical analysis was done using MINITAB® Release 14.1, (MINITAB Inc., 111222333, 2003).

\section{Results}

\section{Chemical composition of seaweeds}

The macro- and micronutrients, vitamins and growth hormones were measured in Enteromorpha intestinalis, Ulva lactuca and Sarconema filiformis and presented in Tables (1). The marine derived foliar fertilizers used in this study had very low NPK values as they were 2.32, 0.40 and 0.50 in the first species, $1.45,0.25$ and 1.32 in the second and 1.63, 0.33 and 0.60 in the third species. All the three algae characterized by high contents of magnesium $\left(268.56 \mathrm{mg} \cdot 100 \mathrm{~g}^{-1}\right.$ in

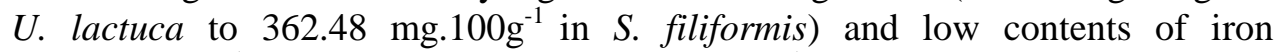
(21.6mg. $100 \mathrm{~g}^{-1}$ in E. intestinalis to $31.05 \mathrm{mg} .100 \mathrm{~g}^{-1}$ in S. filiformis). Calcium was high in both E. intestinalis and U. Lactuca, but low in S. filiformis.

Table (1): Macro-, micronutrients, vitamins and growth hormones measured in explored algae.

\begin{tabular}{|l|c|c|c|c|c|c|c|c|c|c|}
\hline \multicolumn{1}{|c|}{ Algae } & $\mathrm{N}$ & $\mathrm{P}$ & $\mathrm{K}$ & $\mathrm{Ca}$ & $\mathrm{Mn}$ & $\mathrm{Mg}$ & $\mathrm{Zn}$ & $\mathrm{Fe}$ & $\mathrm{A}$ & $\mathrm{C}$ \\
\hline E. intestinalis & $\mathbf{2 . 3 2}$ & $\mathbf{0 . 4 0}$ & $\mathbf{0 . 5 0}$ & $\mathbf{1 7 3 . 1}$ & $\mathbf{7 2 . 8}$ & $\mathbf{2 5 3 . 7}$ & $\mathbf{2 1 . 9}$ & $\mathbf{2 1 . 6}$ & $\mathbf{2 1 6 6 . 7}$ & $\mathbf{2 0 . 9}$ \\
\hline U. lactuca & $\mathbf{1 . 6 3}$ & $\mathbf{0 . 3 3}$ & $\mathbf{0 . 6 0}$ & $\mathbf{2 0 3 . 9}$ & $\mathbf{1 1 6 . 8}$ & $\mathbf{2 6 8 . 6}$ & $\mathbf{8 2 . 6}$ & $\mathbf{2 6 . 6}$ & $\mathbf{2 5 8 3 . 3}$ & $\mathbf{2 7 . 6}$ \\
\hline S. filiformis & $\mathbf{1 . 4 5}$ & $\mathbf{0 . 2 5}$ & $\mathbf{1 . 3 2}$ & $\mathbf{8 4 . 6}$ & $\mathbf{6 7 . 8}$ & $\mathbf{3 6 2 . 5}$ & $\mathbf{7 7 . 9}$ & $\mathbf{3 1 . 1}$ & $\mathbf{1 5 8 3 . 3}$ & $\mathbf{1 8 . 5}$ \\
\hline
\end{tabular}

$\mathrm{N}$, nitrogen, $\mathrm{P}$, phosphorous, and $\mathrm{K}$, potassium measured as percentages; $\mathrm{Ca}$, calcium, Mn, manganese, $\mathrm{Mg}$, magnesium, Zn, zinc and Fe, iron measured as mg. $100 \mathrm{~g}^{-1}$; A, vitamin A measured as IU.100g ${ }^{-1}$ and C, vitamin C measured as mg. $100 \mathrm{~g}^{-1}$.

The zinc contents were varied from $21.85 \mathrm{mg} 100 \mathrm{~g}^{-1}$ in $E$. intestinalis to $82.62 \mathrm{mg} .100 \mathrm{~g}^{-1}$ in $U$. lactuca. The later species possessed the highest value of manganese (116.82mg. $\left.100 \mathrm{~g}^{-1}\right)$. U. lactuca scored the highest content of vitamin A 
(2583.30 IU.100g $\mathrm{g}^{-1}$ ), followed by E. intestinalis (2166.70 IU.100g $\mathrm{g}^{-1}$ ) and about the half was found in $S$. filiformis (1583.3 IU.100g $\mathrm{g}^{-1}$ ). Vitamin C was also low in $S$. filiformis (18.48mg.100g $\left.\mathrm{g}^{-1}\right)$ and high in the other species $\left(20.93-27.58 \mathrm{mg} .100 \mathrm{~g}^{-1}\right.$ for E. intestinalis and U. lactuca, in respectively).

Gibberellins, indole acetic acid, abscisic acid, and cytokinins were identified and measured in different used algae (Table 2). S. filiformis characterized by high content of gibbrellic acid $\left(58 \mathrm{mg} .100 \mathrm{~g}^{-1}\right)$ and low content of abscisic acid (1.29 mg.100g $\left.\mathrm{g}^{-1}\right)$. Cytokinin was $34.4 \mathrm{mg} 100 \mathrm{~g}^{-1}$ and indoleacetic acid was $3.18 \mathrm{mg} .100 \mathrm{~g}^{-1}$ in this alga. E. intestinalis and U. lactuca showed a high contents of cytokinin (46.3 and $65.4 \mathrm{mg} .100 \mathrm{~g}^{-1}$, respectively) and gibbrellic acid (25.5 mg. $100 \mathrm{~g}^{-1}$ and $37.0 \mathrm{mg} .100 \mathrm{~g}^{-1}$, respectively).

Table (2): The growth hormone contents $\left(\mathrm{mg} 100 \mathrm{~g}^{-1}\right)$ measured in different algae.

\begin{tabular}{|l|c|c|c|c|}
\hline \multicolumn{1}{|c|}{ Algae } & Gibbrellic acid & Indole acetic acid & Abscisic acid & Cytokinin \\
\hline E. intestinalis & 25.50 & 0.34 & 0.47 & 46.30 \\
\hline U. lactuca & 37.00 & 3.12 & 1.42 & 65.40 \\
\hline S. filiformis & $\mathbf{5 8 . 0 0}$ & 3.18 & 1.29 & 34.40 \\
\hline
\end{tabular}

Effects of algal extracts on vegetative characters during growth period of Vicia faba (Plant height)

Table (3) shows the variability of the plant heights with different algal concentrations, which measured after 49, 70 and 91 days of sawing date. It is worth to mention that plants were sprayed two weeks before each of these time schedule. After 49 days of sawing date, S. filiformis had a greater effect on the plant height than the other algal species with prominent at 0.05 concentration than its effect at 0.10 and 0.15 concentrations.

Table (3): Effects of algal concentrations on Vicia faba plant heights (mean \pm SD cm) measured after 49, 70, and 91 days after sawing.

\begin{tabular}{|l|c|c|c|c|}
\hline Treatment & Conc. & After 49 days & After 70 days & After 91 days \\
\hline Control & $\mathbf{0 . 0 0}$ & $\mathbf{2 1 . 2 8} \pm \mathbf{1 . 7 9}$ & $\mathbf{3 1 . 7 9} \pm \mathbf{4 . 4 6}$ & $\mathbf{4 7 . 9 2} \pm \mathbf{6 . 9 5}$ \\
\hline \multirow{3}{*}{ E. intestinalis } & $\mathbf{0 . 0 5}$ & $\mathbf{2 5 . 1 9} \pm \mathbf{6 . 3 4}$ & $\mathbf{3 8 . 6 0} \pm \mathbf{7 . 4 4}$ & $\mathbf{5 2 . 6 7} \pm \mathbf{8 . 0 9}$ \\
\cline { 2 - 5 } & $\mathbf{0 . 1 0}$ & $\mathbf{2 7 . 0 7} \pm \mathbf{5 . 5 2}$ & $\mathbf{4 4 . 8 0} \pm \mathbf{6 . 5 5}$ & $\mathbf{6 4 . 3 8} \pm \mathbf{5 . 8 5}$ \\
\cline { 2 - 5 } & $\mathbf{0 . 1 5}$ & $\mathbf{2 7 . 5 9} \pm \mathbf{4 . 0 2}$ & $\mathbf{4 4 . 1 4} \pm \mathbf{4 . 3 2}$ & $\mathbf{6 0 . 8 8} \pm \mathbf{1 1 . 8 0}$ \\
\hline \multirow{4}{*}{ U. lactuca } & $\mathbf{0 . 0 5}$ & $\mathbf{2 1 . 3 3} \pm \mathbf{3 . 6 5}$ & $\mathbf{3 5 . 2 7} \pm \mathbf{7 . 4 4}$ & $\mathbf{5 3 . 5 7} \pm \mathbf{7 . 6 6}$ \\
\cline { 2 - 5 } & $\mathbf{0 . 1 0}$ & $\mathbf{2 3 . 5 9} \pm 3.51$ & $\mathbf{3 6 . 6 3} \pm \mathbf{7 . 4 5}$ & $\mathbf{5 1 . 2 5} \pm \mathbf{8 . 0 1}$ \\
\cline { 2 - 5 } & $\mathbf{0 . 1 5}$ & $\mathbf{2 4 . 8 1} \pm \mathbf{4 . 1 9}$ & $\mathbf{3 9 . 8 8} \pm \mathbf{5 . 0 1}$ & $\mathbf{4 6 . 2 5} \pm \mathbf{1 6 . 1 8}$ \\
\hline \multirow{3}{*}{ S. filiformis } & $\mathbf{0 . 0 5}$ & $\mathbf{3 3 . 1 8} \pm \mathbf{2 . 9 5}$ & $\mathbf{4 9 . 7 3} \pm \mathbf{7 . 6 5}$ & $\mathbf{5 6 . 3 0} \pm \mathbf{1 3 . 1 3}$ \\
\cline { 2 - 5 } & $\mathbf{0 . 1 0}$ & $\mathbf{3 1 . 1 5} \pm \mathbf{3 . 6 1}$ & $\mathbf{4 6 . 1 9} \pm \mathbf{1 2 . 0 5}$ & $\mathbf{6 3 . 7 8} \pm \mathbf{8 . 4 4}$ \\
\cline { 2 - 5 } & $\mathbf{0 . 1 5}$ & $\mathbf{3 0 . 4 6} \pm \mathbf{2 . 2 8}$ & $\mathbf{4 7 . 9 1} \pm \mathbf{4 . 7 8}$ & $\mathbf{6 7 . 0 0} \pm \mathbf{1 0 . 5 8}$ \\
\hline
\end{tabular}


E. intestinalis and $U$. lactuca (except the lower concentration) affected also the plant heights of $V$. faba when compared with the control. After 70 days of sawing date, all algae showed a superior effect of one third than the control, and the $S$. filiformis had also the greatest effect on the plant height as compared with the other species.

The effects of all concentrations of $U$. lactuca were close. On the other hand, the plant heights of $V$. faba increased with the increased concentration of $E$. intestinalis. After 91 days of sawing date, the all algae had a better effect than the control except for those treated with $U$. lactuca at concentration 0.15 and $E$. intestinalis at concentration 0.5. S. filiformis at 0.15 had the greatest effect on the plant height as compared with the other species.

\section{Number of branches per plant}

Almost all algal treatment had a similar effect on the number of branches per plant (Table 4). After 49 days of sawing date, three branches were approximately emerged on broad bean plants treated with $U$. lactuca and E. intestinalis; meanwhile the average on the plants treated by $S$. filiformis appeared similar with control plants. The average number of branches per plant, after 70 days of sawing date increased by 1 to 2 branches and $U$. lactuca had the greatest effect on number of the branches per plant as compared with the other species. While, after 91 days of sawing date, the number of branches per plant were remained more or less similar to that of the second treatment.

Table (4): Effects of algal concentrations on Vicia faba number of branches (mean \pm SD) measured after 49, 70 and 90 days after sawing.

\begin{tabular}{|c|c|c|c|c|}
\hline Treatment & Conc. & After 49 days & After 70 days & After 91 days \\
\hline Control & 0.00 & $2.81 \pm 0.98$ & $2.86 \pm 1.03$ & $2.83 \pm 1.03$ \\
\hline \multirow{3}{*}{ E. intestinalis } & 0.05 & $3.38 \pm 1.15$ & $4.25 \pm 1.29$ & $3.22 \pm 0.67$ \\
\hline & 0.10 & $2.88 \pm 0.89$ & $3.50 \pm 0.85$ & $3.50 \pm 1.07$ \\
\hline & 0.15 & $3.19 \pm 0.91$ & $3.13 \pm 1.25$ & $5.13 \pm 4.02$ \\
\hline \multirow{3}{*}{ U. lactuca } & 0.05 & $3.69 \pm 0.70$ & $4.93 \pm 1.22$ & $4.57 \pm 1.09$ \\
\hline & 0.10 & $3.19 \pm 0.40$ & $5.00 \pm 1.86$ & $4.92 \pm 1.93$ \\
\hline & 0.15 & $3.69 \pm 1.25$ & $4.50 \pm 1.51$ & $3.88 \pm 1.67$ \\
\hline \multirow{3}{*}{ S. filiformis } & 0.05 & $2.44 \pm 0.63$ & $4.00 \pm 1.77$ & $3.60 \pm 1.84$ \\
\hline & 0.10 & $2.63 \pm 0.72$ & $3.31 \pm 1.35$ & $4.33 \pm 1.94$ \\
\hline & 0.15 & $2.63 \pm 0.96$ & $3.44 \pm 1.09$ & $4.00 \pm 2.10$ \\
\hline
\end{tabular}

\section{Number of the leaves/plat and leaf area}

The number of leaves per plant of Vicia faba (Table 5) showed that after 49 days, $E$. intestinalis and $U$. lactuca had a greater effect than $S$. filiformis, which was also less than the control plants. After 70 days, all algae had greater effects on 
the number of leaves of Vicia faba. After 75 days, the control plants produced leaves in a number approximately similar to E. intestinalis at 0.05 and 0.01 and $U$. lactuca at 0.05 and S. filiformis at 0.15 ; meanwhile the other concentrations produced leaves more than the control plants. It should be mentioned that no sign of nutrient deficiency or plant disease had been seen during the growth period of Vicia faba. The effects of the first algal treatments on leaf area (Table 5) showed that all concentrations increased the leaf area by $1-2 \mathrm{~cm}^{2}$ compared with control plants. After the second treatments, the leaf areas appeared more or less similar to control except at 0.05 concentration of E. intestinalis where the area increased by $5.5 \mathrm{~cm}^{2}$.

Table (5): Effects of algal concentrations on Vicia faba number of leaves and leaf area (mean \pm SD) measured after 49, 70, and 91 days after seed sawing.

\begin{tabular}{|c|c|c|c|c|c|c|}
\hline \multirow[b]{2}{*}{ Treatment } & \multirow[b]{2}{*}{ Conc. } & \multicolumn{3}{|c|}{ Number of leaves } & \multicolumn{2}{|c|}{ Leaf area $\left(\mathrm{cm}^{2}\right)$} \\
\hline & & $\begin{array}{c}\text { After } 49 \\
\text { days }\end{array}$ & $\begin{array}{c}\text { After } 70 \\
\text { days }\end{array}$ & $\begin{array}{c}\text { After } 91 \\
\text { days }\end{array}$ & $\begin{array}{c}\text { After } 49 \\
\text { days }\end{array}$ & $\begin{array}{c}\text { After } 70 \\
\text { days }\end{array}$ \\
\hline Control & 0.00 & $21.1 \pm 6.6$ & $33.2 \pm 11.6$ & $64.1 \pm 11.9$ & $9.2 \pm 1.2$ & $20.2 \pm 25.7$ \\
\hline \multirow{3}{*}{ E. intestinalis } & 0.05 & $24.9 \pm 8.9$ & $52.4 \pm 17.8$ & $59.8 \pm 20.3$ & $13.4 \pm 1.5$ & $25.7 \pm 35.2$ \\
\hline & 0.10 & $21.7 \pm 6.7$ & $47.0 \pm 15.8$ & $67.9 \pm 14.9$ & $12.6 \pm 1.6$ & $22.8 \pm 26.5$ \\
\hline & 0.15 & $23.9 \pm 5.9$ & $43.8 \pm 13.4$ & $77.1 \pm 13.4$ & $12.2 \pm 1.5$ & $17.8 \pm 26.3$ \\
\hline \multirow{3}{*}{ U. lactuca } & 0.05 & $23.8 \pm 3.5$ & $46.1 \pm 11.7$ & $61.4 \pm 14.4$ & $11.9 \pm 1.9$ & $20.6 \pm 27.3$ \\
\hline & 0.10 & $24.0 \pm 4.9$ & $51.3 \pm 14.8$ & $73.6 \pm 21.1$ & $13.8 \pm 1.5$ & $21.9 \pm 29.3$ \\
\hline & 0.15 & $24.1 \pm 6.7$ & $51.2 \pm 15.7$ & $80.8 \pm 24.9$ & $12.1 \pm 2.0$ & $22.2 \pm 27.4$ \\
\hline \multirow{3}{*}{ S. filiformis } & 0.05 & $20.0 \pm 3.8$ & $58.5 \pm 17.1$ & $81.6 \pm 16.6$ & $13.8 \pm 2.1$ & $22.0 \pm 26.2$ \\
\hline & 0.10 & $19.6 \pm 4.7$ & $52.1 \pm 13.7$ & $76.9 \pm 19.6$ & $13.3 \pm 2.9$ & $20.7 \pm 26.7$ \\
\hline & 0.15 & $17.8 \pm 7.7$ & $49.1 \pm 16.3$ & $69.7 \pm 22.9$ & $11.8 \pm 1.3$ & $20.3 \pm 24.6$ \\
\hline
\end{tabular}

\section{Effects of algal extracts on criteria of yield components in Vicia faba}

The seed yield components of Vicia faba (Table 6) was measured at the end of the growing season (i.e. 91 days after seed sawing). All these criteria were superior in measurements than with the control. Exception was found for the measurements of the average length of the five buds. All algal applications increased the number of flowers from 41.5 to 93.38 than it was found with control (36.86). The effect was increased from 0.05 to 0.10 concentrations, but lower again at concentration 0.15 , except with $U$. lactuca that had the greatest number of flowers per plant (93.38). The lack of adequate pollination and reduced seed setting can be major constraints to yield. Many flowers drop and seed abortions were found as the average number of buds (ANB) and the average number of pods are greatly decreased in comparison with the average number of flowers (Table 6). For all algal applications, the number of flowers was from 27.13 to 67.44 and 
the number of pods was 4.18-10.88 per plant. The number of flowers and pods increased with the increases in algal concentrations from 0.05 to 0.15 , except $\mathrm{S}$. filiformis at 0.15 .

Table (6): The average number of flowers (ANF), buds (ANB), pods (ANP), height of first bud (AHFB) per plants as well as the average length of 5-pods (AL5P), the total number of seeds (TNOS) and their weights (TS Wt) per plot.

\begin{tabular}{|c|c|c|c|c|c|c|c|c|}
\hline Treatments & Conc. & ANF & ANB & ANP & AHFP & AL5P & TNOS & TS Wt \\
\hline Control & $\mathbf{0}$ & 36.86 & 27.71 & 3.92 & 10.75 & 7.47 & 164 & 175.3 \\
\hline \multirow{3}{*}{ E. intestinalis } & 0.05 & 47.64 & 27.13 & 4.18 & 21.00 & 9.09 & 179 & 203.3 \\
\hline & 0.1 & 81.58 & 45.58 & 5.58 & 12.58 & 8.33 & 266 & 394.4 \\
\hline & 0.15 & 63.36 & 48.55 & 6.36 & 18.18 & 7.60 & 250 & 376.1 \\
\hline \multirow{3}{*}{ U. lactuca } & 0.05 & 66.63 & 48.75 & 5.88 & 12.63 & 5.86 & 220 & 304.9 \\
\hline & 0.1 & 72.21 & 55.50 & 6.07 & 13.57 & 6.56 & 211 & 311.7 \\
\hline & 0.15 & 93.38 & 67.44 & 10.88 & 16.88 & 7.60 & 267 & 423.6 \\
\hline \multirow{3}{*}{ S. filiformis } & 0.05 & 69.06 & 49.69 & 8.25 & 13.33 & 7.95 & 356 & 475.3 \\
\hline & 0.1 & 71.50 & 64.75 & 10.31 & 19.56 & 9.00 & 600 & 980.5 \\
\hline & 0.15 & 45.67 & 41.19 & 9.17 & 25.83 & 8.37 & 254 & 443.3 \\
\hline
\end{tabular}

The average height of the first pod (AHFP) was ranged from 12.58 to $25.83 \mathrm{~cm}$ for all algal applications and $10.75 \mathrm{~cm}$ for the control (Table 7). The height increased with the increasing of algal concentration, except with $E$. intestinalis, where the lower concentration corresponded high position of the first pod. The average length of five pods (AL5P) fluctuated between $6.56 \mathrm{~cm}$ by application of $U$. lactuca at concentration 0.05 to $9.09 \mathrm{~cm}$ by application of $E$. intestinalis at the same concentration. The length of pods in control $(7.6 \mathrm{~cm})$ was approximately comparable to E. intestinalis and $U$. lactuca at 0.15 and to $S$. filiformis at concentration 0.05 (Table 7).

Table (7): General Linear Model of ANOVA of vegetative measures of Vicia faba. Values in the cells are the $F$ variance ratio (above) and $P$ level of probability (below).

\begin{tabular}{|c|c|c|c|c|c|c|c|c|}
\hline \multirow[b]{2}{*}{$\begin{array}{c}\text { Source of } \\
\text { variance }\end{array}$} & \multicolumn{3}{|c|}{ Plant height (cm) } & \multicolumn{3}{|c|}{ Number of branches/plant } & \multicolumn{2}{|c|}{ Leaf area index } \\
\hline & $\begin{array}{c}\text { After } 49 \\
\text { days }\end{array}$ & $\begin{array}{c}\text { After } 70 \\
\text { days }\end{array}$ & $\begin{array}{c}\text { After } 91 \\
\text { days }\end{array}$ & $\begin{array}{c}\text { After } 49 \\
\text { days }\end{array}$ & $\begin{array}{c}\text { After } 70 \\
\text { days }\end{array}$ & $\begin{array}{c}\text { After } 91 \\
\text { days }\end{array}$ & $\begin{array}{c}\text { After } 49 \\
\text { days }\end{array}$ & $\begin{array}{c}\text { After 70 } \\
\text { days }\end{array}$ \\
\hline \multirow{2}{*}{ Species } & 45.76 & 20.73 & 9.95 & 10.21 & 8.98 & 0.70 & 0.45 & 0.67 \\
\hline & 0.000 & 0.000 & 0.000 & 0.000 & 0.000 & 0.496 & 0.640 & 0.512 \\
\hline \multirow{2}{*}{ Conc. } & 30.52 & 26.8 & 9.06 & 1.97 & 10.18 & 5.23 & 55.67 & 10.56 \\
\hline & 0.000 & 0.000 & 0.000 & 0.120 & 0.000 & 0.002 & 0.000 & 0.000 \\
\hline Species & 7.33 & 3.62 & 30.12 & 1.69 & 1.35 & 1.49 & 2.18 & 4.02 \\
\hline by Conc. & 0.000 & 0.000 & 0.007 & 0.126 & 0.238 & 0.188 & 0.047 & 0.001 \\
\hline
\end{tabular}

The algal extracts stimulated the crop yield of Vicia faba as it was obvious from the total number of seeds and their weight per plot (Table 7). Where the total number of seeds was $164 \mathrm{gm}$. plot $^{-1}$ for control, it was from 179 by the application of 0.05 of E. intestinalis to 600 by application of 0.10 of S. filiformis. The range with algal treatments corresponded 394.4 to 980.5 gm.plot ${ }^{-1}$. The

Egyptian J. of Phycol. Vol. 12, $2011 \quad$ - 78 - 
number of seeds and the corresponding weight increased by increasing algal concentrations from 0.05 to 0.10 , and then decreased again by application of 0.15 of all algae.

\section{Significance of the measurements characters of Vicia faba}

The vegetative and yield criteria were analyzed using ANOVA and the results of this analysis are listed in Table (8). The high ANOVA F-tests with the low p-level in these tables indicate that there was a significant evidence for effects of different algae, different concentrations and their combinations on almost criteria of $V$. faba. Exception was found for the number of branches, leaf area index, and in lesser extent for the number and length of pods as the $F$ values was low with p-value exceed 0.05 .

Table 8: General Linear Model of ANOVA of yield measures of Vicia faba.

\begin{tabular}{|c|c|c|c|c|c|c|c|}
\hline $\begin{array}{c}\text { Source of } \\
\text { variance }\end{array}$ & Flowers & $\begin{array}{c}\text { Number } \\
\text { of buds }\end{array}$ & $\begin{array}{c}\text { Number of } \\
\text { pods }\end{array}$ & $\begin{array}{c}\text { Height of } \\
\text { first pod }\end{array}$ & $\begin{array}{c}\text { Length of 5 } \\
\text { pods }\end{array}$ & $\begin{array}{c}\text { Number } \\
\text { of seeds }\end{array}$ & $\begin{array}{c}\text { Seeds } \\
\text { weight }\end{array}$ \\
\cline { 2 - 8 } & $\begin{array}{c}\text { After 70 } \\
\text { days }\end{array}$ & $\begin{array}{c}\text { After 91 } \\
\text { days }\end{array}$ & $\begin{array}{c}\text { After } 91 \\
\text { days }\end{array}$ & $\begin{array}{c}\text { After 91 } \\
\text { days }\end{array}$ & $\begin{array}{c}\text { After } 91 \\
\text { days }\end{array}$ & $\begin{array}{c}\text { After 91 } \\
\text { days }\end{array}$ & $\begin{array}{c}\text { After 91 } \\
\text { days }\end{array}$ \\
\hline Species & $\mathbf{8 . 8 6}$ & $\mathbf{1 5 . 1 4}$ & 11.72 & $\mathbf{8 . 4 0}$ & 7.24 & $\mathbf{2 8 . 6 6}$ & $\mathbf{2 6 . 1 6}$ \\
& $\mathbf{0 . 0 0 0}$ & $\mathbf{0 . 0 0 0}$ & $\mathbf{0 . 0 0 0}$ & $\mathbf{0 . 0 0 0}$ & $\mathbf{0 . 0 0 0}$ & $\mathbf{0 . 0 0 0}$ & $\mathbf{0 . 0 0 0}$ \\
\hline Conc. & $\mathbf{4 1 . 7 2}$ & $\mathbf{4 6 . 3 1}$ & $\mathbf{1 7 . 9 2}$ & $\mathbf{2 1 . 8 3}$ & $\mathbf{4 . 6 2}$ & $\mathbf{1 1 . 2 6}$ & $\mathbf{1 7 . 7 2}$ \\
& $\mathbf{0 . 0 0 0}$ & $\mathbf{0 . 0 0 0}$ & $\mathbf{0 . 0 0 0}$ & $\mathbf{0 . 0 0 0}$ & $\mathbf{0 . 0 0 4}$ & $\mathbf{0 . 0 0 0}$ & $\mathbf{0 . 0 0 0}$ \\
\hline $\begin{array}{c}\text { Species by } \\
\text { Conc. }\end{array}$ & $\mathbf{9 . 4 7}$ & $\mathbf{7 . 6 3}$ & $\mathbf{4 . 1 7}$ & $\mathbf{7 . 1 4}$ & $\mathbf{1 . 8 6}$ & $\mathbf{3 . 6 3}$ & $\mathbf{3 . 9 0}$ \\
\hline
\end{tabular}

The nutritional composition of Vicia faba

Proximate nutritional composition of broad bean was represented in Table (9). The treated samples of broad beans contained higher contents of ash (10.01 to

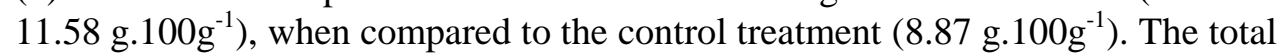
carbohydrates in treated samples $\left(44.2-53.7 \mathrm{~g} .100 \mathrm{~g}^{-1}\right)$ were more or less similar to control sample $\left(53.8 \mathrm{~g} \cdot 100 \mathrm{~g}^{-1}\right)$.

Table (9): Proximate nutritional composition of broad bean expressed as $\mathrm{g.100g}^{-1}$

\begin{tabular}{|c|c|c|c|c|c|c|}
\hline Treatment & Conc. & Ash & Carbohydrates & Proteins & Lipids & Fibers \\
\hline Control & $\mathbf{0 . 0 0}$ & $\mathbf{8 . 8 7}$ & $\mathbf{5 3 . 8 0}$ & 16.9 & 1.93 & 7.0 \\
\hline \multirow{3}{*}{ E. intestinalis } & $\mathbf{0 . 0 5}$ & 11.58 & 50.10 & 19.9 & 1.33 & 5.5 \\
\cline { 2 - 7 } & $\mathbf{0 . 1 0}$ & 10.58 & 51.70 & 20.8 & 1.13 & 4.5 \\
\cline { 2 - 7 } & $\mathbf{0 . 1 5}$ & 11.44 & 49.00 & 22.1 & 1.53 & 5.5 \\
\hline \multirow{4}{*}{ U. lactuca } & $\mathbf{0 . 0 5}$ & 11.58 & $\mathbf{5 0 . 1 0}$ & 20.1 & 1.33 & 5.5 \\
\cline { 2 - 7 } & $\mathbf{0 . 1 0}$ & 10.01 & 46.00 & 23.8 & 1.83 & 7.5 \\
\cline { 2 - 7 } & $\mathbf{0 . 1 5}$ & 11.30 & 47.50 & 20.8 & 1.33 & 8.5 \\
\hline \multirow{3}{*}{ S. filiformis } & $\mathbf{0 . 0 5}$ & 10.01 & $\mathbf{5 3 . 7 0}$ & 20.8 & 1.13 & 5.5 \\
\cline { 2 - 7 } & $\mathbf{0 . 1 0}$ & 10.44 & $\mathbf{5 0 . 6 0}$ & 23.6 & 1.33 & 4.0 \\
\cline { 2 - 7 } & $\mathbf{0 . 1 5}$ & 10.87 & 44.20 & 25.9 & 1.51 & 7.5 \\
\hline
\end{tabular}


The protein in the seeds of treated samples was greater $(19.9-25.9 \mathrm{~g} .100 \mathrm{~g}$ $\left.{ }^{1}\right)$ than control $\left(16.9 \mathrm{~g} .100 \mathrm{~g}^{-1}\right)$; and percentage increased by the increase of algal concentration except at 0.15 concentration of $U$. lactuca. The maximum protein content $\left(25.9\right.$ g. $\left.100 \mathrm{~g}^{-1}\right)$ was found when the plants treated with $S$. filiformis. Both total lipids (1.13-1.83 g. $\left.100 \mathrm{~g}^{-1}\right)$ and crud fibers (4.0-8.5 g. $\left.100 \mathrm{~g}^{-1}\right)$ were less varied from the control $\left(7.0 \mathrm{~g} .100 \mathrm{~g}^{-1}\right)$.

\section{Discussion}

The marine derived fertilizers used in this study had very low NPK values. The NPK ratios were 2.32-0.40-0.50 in E. intestinalis, 1.45-0.25-1.32 in $S$. filiformis and 1.63-0.33-0.60 in $U$. lactuca. It would be difficult to meet the macronutrient needs of a growing plant when used these ratios as soil fertilizers. Although, many studies (e.g., Chauhan, 2002; Garg and Chauhan, 2003) have been shown the dried powdered seaweeds as a good source of manure when mixed with soil in small quantities, other studies suggested algae as foliar application (e.g., Saxena et al., 2004; Chauhan, 2005). So that, using these percentages as foliar fertilizers with multiple applications in this study would be efficient to supply the growing plants with sufficient nutrients.

The advantages of using seaweeds as plant fertilizers could be coming from their micronutrients and other algal constituents. Blunden and Wildgoose (1977); Smith and van Staden (1983) have concluded that trace elements in very low quantity form a significant proportion of the total requirements of the crops. The present applications had an advantage where no signs of mineral deficiency or microbial attack had been detected on either the broad bean or maize. $\mathrm{Ca}$ in the present seaweeds was $173.08,84.62$ and $203.85 \mathrm{mg} .100 \mathrm{~g}^{-1}$; Mn was 72.8, 67.76, and 116.82; $\mathrm{Mg}$ was 253.73, 362.48 and 268.56; $\mathrm{Zn}$ was 21.85, 77.88, and 82.62; $\mathrm{Fe}$ was $21.6,31.05$, and $26.63 \mathrm{mg} .100 \mathrm{~g}^{-1}$ in E. intestinalis, S. filiformis and $U$. lactuca, respectively. The mineral contents of the present algae were higher than those measured by Hong et al. (2007) in Vietnamese seaweeds.

Vitamins are important co-enzyme factors that play an important role for plant health. In the present study, greater amounts of vitamin A were recorded as $2583.30 \mathrm{IU} .100 \mathrm{~g}^{-1}$ in U. lactuca, $2166.70 \mathrm{IU} .100 \mathrm{~g}^{-1}$ in E. intestinalis and 1583.3 IU. $100 \mathrm{~g}^{-1}$ in S. filiformis. Three pro- vitamins are known as precursors of vitamin $A$ in the algae, $\alpha, \beta$-and $\gamma$-carotenes (Delia, 2001). Other important algal carotenoids include lycopene, lutein, zeaxanthin and B-cryptoxanthin (Francis $\boldsymbol{e t}$ al., 2007; Salah El Din et al., 2008; Vílchez et al., 2011) and all have antioxidant effects. The levels of vitamin $\mathrm{C}$ in the present study were $20.93 \mathrm{mg} .100 \mathrm{~g}^{-1}$ in $E$. intestinalis, $27.58 \mathrm{mg} .100 \mathrm{~g}^{-1}$ in U. lactuca, and $18.48 \mathrm{mg}^{-100 \mathrm{~g}^{-1}}$ in S. filiformis and these were higher than those measured by other authors (e.g., Burtin, 2003; Hong et al., 2007). 
In addition to macro-, micronutrients and vitamins, seaweed components such as cytokinins, auxins, and abscisic acid (ABA)-like growth substances affect cellular metabolism in treated plants leading to enhanced growth and crop yield (Durand et al., 2003; Stirk et al., 2003; Ordog et al., 2004). Gibberellic acid, in the present study, was $25.5,58.0$ and $37.0 \mathrm{mg}^{-100 \mathrm{~g}^{-1}}$; Indole acitic acid was 0.34 , 3.18 and $3.12 \mathrm{mg} 100 \mathrm{~g}^{-1}$; abscisic acid was $0.47,1.29$ and $1.42 \mathrm{mg} .100 \mathrm{~g}^{-1}$; and cytokinin was $46.3,34.4$ and $65.4 \mathrm{mg} .100 \mathrm{~g}^{-1}$ in E. intestinalis, S. filiformis and $U$. lactuca, respectively. The hormonal contents of the present algae were higher than those measured by Hong et al. (2007) in Vietnamese seaweeds. The seaweeds was sprayed in low concentrations $(0.05,0.10$ and $0.15 \mathrm{wt} / \mathrm{wt})$ and many studies showed that the bioactive at low concentrations (diluted as 1:1000 or more) induced growth enhancement (Crouch and van Staden, 1993). Although many of the various chemical components of seaweed extracts and their modes of action remain unknown, it is plausible that these components exhibit synergistic activity (Fornes et al., 2002; Vernieri et al., 2005). The active substances in the seaweed extracts must therefore be capable of having an effect at a low concentration. In addition, seaweeds are a source of unusual and complex polysaccharides, not present in land plants, and considered biologically active substances (Duarte $\boldsymbol{e t}$ al., 2001). For example, the green seaweeds (Ulva and Enteromorpha) contain sulfated mucilages (glucuronoxylorhamnans) and the red seaweeds (Sarconema) contain furcellaran and rhodymenan, all have antifungal activities (Rioux $\boldsymbol{e t}$ al., 2007).

The vegetative and yield criteria indicated a significant evidence for effects of different algae, different concentrations and their combinations on almost criteria of Vicia faba. Exception was found for the number of branches, leaf area index, and in lesser extent for the number and length of pods. A month after seed sawing, all the algal treatments initiated the plant growth to variable heights that were greater than the control treatment by 4 to $13.5 \mathrm{~cm}$. This was also pronounced after another month as the height of treated plants exceeded the control by one third. The $S$. filiformis had the greatest effect on the plant height as compared with other species. By the end of the vegetative growth, the plant treated with the green species (U. lactuca and E. intestinalis) had heights more or less similar to control, meanwhile S. filiformis initiated more plant heights (75-85 $\mathrm{cm})$ than the control $(65 \mathrm{~cm})$. In this connection, Nakao et al. (1994) proved that hot water extract of Chlorella vulgaris promoted radish shoot and root growth. Furthermore, present results are in a good accordance with those of van Staden et al. (1995) who observed an increase in root and shoot growth in three species of Eucalyptus treated with seaweeds concentrate (Kelpak). Also El-Sheekh and ElSaied (2000) stated that the crude extracts from different seaweeds showed increase of length of the main root and shoot system of Vicia faba. 
All the algal treatments initiated more leaves by time in a manner corresponded to the increased plant heights. For control plants, the mean number of leaves was increased from 21 leaves a month after planting to 33 by the second month then by 64 leaves after the third month. For plants treated with $E$. intestinalis, the mean number of leaves was 22-25 at first month, 44-53 at second month and 60-77 leaves at the third month. For $S$. filiformis, these numbers were 17-20, 44-53 and 70-82, respectively. For $U$. lactuca, these numbers were 24, 4651 and 61-81, respectively. Thirumaran et al. (2009) proved that the seaweed liquid fertilizer enhance the growth and yield parameters such as (shoot length, root length, number of lateral roots, leaves, vegetables, and weight of vegetables as well as the photosynthetic pigments.

The number of branches of treated Vicia faba plants did not greatly depart from the control as it was 3 or 4 branches per plant but rarely 5 . The leaf area index of treated Vicia faba plants did not also greatly depart from the control after the first month; it was $9.19 \mathrm{~cm}^{2}$ for the control and $11-13 \mathrm{~cm}^{2}$ for algal treatments. After two months (60 days after sowing date), the leaf area index was $20 \mathrm{~cm}^{2}$ for the control and $18-25 \mathrm{~cm}^{2}$ for the treated plants. The low concentration $(0.05)$ of E. intestinalis and S. filiformis and the high concentration (0.15) of U. lactuca were responsible for the wider the area of the Vicia faba plants. In a recent study (Rayorath et al., 2008), extracts of A. nodosum have been shown to enhance Arabidopsis height and number of leaves at concentrations of $1 \mathrm{~g} \mathrm{l}^{-1}$. Seaweeds enhance plant chlorophyll content (Blunden et al., 1997).

The results showed that all algal applications increased the number of flowers from 41.5 to 93.38 than it was found with control (36.86). The effect increased from 0.05 to 0.10 concentrations, but lower again at concentration 0.15 , except with $U$. lactuca that had the maximum number of flowers per plant (93.38). The results showed that many flowers drop and seed abortions were found as the average number of buds and the average number of pods are greatly decreased in comparison with the average number of flowers. For all algal applications, the number of flowers was ranged from 27.13 to 67.44 and the number of pods was 4.18-10.88 per plant. The number of flowers and pods increased with the increases in algal concentrations from 0.05 to 0.15 , except $S$. filiformis at 0.15 . In many crops, yield is associated with the number of flowers at maturity (Arthur et al., 2003). As the onset and development of flowering and the number of flowers produced are linked to the developmental stage of plants, seaweed extracts probably encourage flowering by initiating robust plant growth.

The average height of the first pod was ranged from 12.58 to $25.83 \mathrm{~cm}$ for all algal applications and $10.75 \mathrm{~cm}$ for the control treatment. The height of the first pod increased with the increasing of algal concentration, except with $E$. intestinalis where the lower concentration corresponded high position of the first pod. The average length of five pods fluctuated between $6.56 \mathrm{~cm}$ by application of 
$U$. lactuca at concentration 0.05 to $9.09 \mathrm{~cm}$ by application of E. intestinalis at the same concentration. The length of pods in control $(7.6 \mathrm{~cm})$ was proximately comparable to $E$. intestinalis and $U$. lactuca at 0.15 and to $S$. filiformis at concentration 0.05 .

The algal extracts stimulated the crop yield of Vicia faba as it is obvious from the total number of seeds and their weight per plot. Where the total number of seeds was 164 per plot for control, it was from 179 by the application of 0.05 of E. intestinalis to 600 by application of 0.10 of S. filiformis. The weight with all algal treatments was from 394.4 to $980.5 \mathrm{gm}$. Seed yield increases in seaweedtreated plants are thought to be associated with the hormonal substances present in the extracts, especially cytokinins (Featonby-Smith, 1983 a, b). Cytokinins have been implicated in nutrient mobilization in vegetative plant organs (Gersani and Kende 1982) as well as reproductive organs (Davey and van Staden, 1978). Such a response indicates that seaweed extracts are involved either in enhancing the mobilization of cytokinins from the roots to the developing fruit, or, more likely, by improving the amount or synthesis of endogenous fruit cytokinins (Hahn $\boldsymbol{e t}$ al., 1974).

The treated samples of broad beans contained higher contents of ash

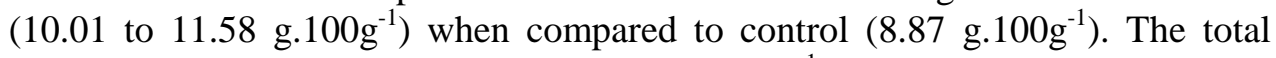
carbohydrates in treated samples $\left(44.2-53.7 \mathrm{~g} .100 \mathrm{~g}^{-1}\right)$ were more or less similar to control $\left(53.8\right.$ g. $\left.100 \mathrm{~g}^{-1}\right)$. The protein treated samples was greater (19.9-25.9 g. $\left.100 \mathrm{~g}^{-1}\right)$ than control $\left(16.9 \mathrm{~g} .100 \mathrm{~g}^{-1}\right)$; and percentage increased by the increase of algal concentration except at 0.15 concentration of $U$. lactuca. The maximum protein content $\left(25.9 \mathrm{~g} .100 \mathrm{~g}^{-1}\right)$ was found when the plants treated with $S$. filiformis. Both total lipids (1.13-1.83 g. $\left.100 \mathrm{~g}^{-1}\right)$ and crud fibers $\left(4.0-8.5 \mathrm{~g} .100 \mathrm{~g}^{-1}\right)$ were less varied from the control $\left(7.0 \mathrm{~g} \cdot 100 \mathrm{~g}^{-1}\right)$. The effect of the nutritive elements on amino acid and protein biosynthesis may be explained through the effective roles of each element. Bloom and Finazzo (1986) reported that, ammonia stimulated the metabolic rate of nitrates causing an increase in total amino acids and protein content in barley plants. Guo et al. (2008) explained the positive effect of $\mathrm{Cu}$ as it increases metallothioneins biosynthesis and its distribution. Sevilla et al. (1982) explained that, manganese increased amino acids biosynthesis through increasing superoxide dismutases enzyme. Taiz and Zeiger (2006) suggested that the increasing of amino acids and protein may be due to the enhancement effect of K on the biosynthesis of RNA. Rufty et al. (1990) stated that amino acids and protein contents were increased because $\mathrm{P}$ increased the bioconversion of nitrate into amino acids. Tabe and Droux (2002) demonstrated that, the S stimulated protein biosynthesis through stimulating the conversion of organic sulfur compounds into S-containing amino acids. Goldgur et al. (2007) pointed to the role of $\mathrm{Zn}$ in the mechanism of changing protein from unfolded to folded state which led to an increase in the protein biosynthesis. 


\section{Conclusion}

In conclusion, application of eco-friendly seaweed fertilizers derived from E. intestinalis, S. filiformis, and $U$. lactuca were effective in increasing the growth and yield parameters. By the end of the season, Vicia faba plants grown with the foliar seaweed application had produced 1.6 to 2.25 folds of the unfertilized controls for E. intestinalis, 2.5 to 5.6 folds using S. filiformis, and 1.7 to 2.4 folds using $U$. lactuca. The present production does not reach the Egyptian yield of feddan. Hence, a soil organic fertilizer via seaweed fertilizers is recommended for attaining better germination, growth and yield.

\section{References}

AOAC (1990). Official Methods of Analysis. $15^{\text {th }}$ Ed. Association of Analytical Chemists. Washington DC, USA.

Agenbag, H. J. C. (1989). Effect of seaweed concentrate on the growth and seed yield of Lupins albus. Applied Plant Science, 3: 114-117.

Aleem, A. A. (1993). The marine Algae of Alexandria, Egypt. Aleem A. A. (Ed.) Faculty of Science, University of Alexandria, Egypt.

Arthur, G. D.; Stirk, W. A. and Studen, V.J. (2003). Effect of a seaweed concentrate on the growth and yield of three varieties of Capsicum annum. South Africa Journal of Botany, 69: 207-211.

Aseri, G. K.; Jain, N.; Panwar, J; Rao, A. V. and Meghwal, P. R. (2008). Biofertilizers improve plant growth, fruit yield, nutrition, metabolism and rhizosphere enzyme activities of Pomegranate (Punica granatum L.) in Indian Thar Desert. Scientia Horticulturae, 117: 130-135.

Bloom, A. J. and Finazzo, J. (1986). The influence of ammonium and chloride on potassium and nitrate absorption by barley roots depends on time of exposure and cultivar. Plant Physiology, 81:67-69.

Blunden, G. and Guiry, M. D. (1991). Agricultural uses of seaweeds and seaweed extracts. Seaweed resources in Europe: Uses and Potentials. John Wileyuc Sons Ltd. p. 65-81.

Blunden, G. and Wildgoose P. B. (1977). The effects of aqueous seaweed extract and kinetin on potato yield. J. Sc. Food Agric., 28:121-125.

Blunden, G.; Jenkins, T. and Liu, Y. (1997). Enhanced leaf chlorophyll levels in plants treated with seaweed extract. J. Appl. Phycol., 8:535-543.

Booth, E. (1966). Some properties of seaweed manures. Proc. Int. Seaweed Symp., 5: 349-357.

Burtin, P. (2003). Nutritional Value of Seaweeds. Electronic Journal of Environmental, Agricultural and Food Chemistry (ISSN: 1579-4377), 2(4):498-503.

Cardozo, K. H. M.; Guaratini, T.; Barros, M. P.; Falca ̃o, V. R.; Tonon, A. P.; Lopes, N. P.; Campos, S.; Torres, M. A.; Souza, A. O.; Colepicolo, 
P. and Pinto, E. (2007). Metabolites from algae with economical impact. Comp. Biochem. Physiol. Toxicol. Pharmacol., 146: 60-78.

Challen, S. B. and Hemingway, J. C. (1965). Growth of higher plants in response to feeding with seaweed extracts. Proc. $5^{\text {th }}$ Int. Seaweed Symp. Halifax. August 25-28.

Chauhan, R. S. (2002). Medical importance of panchagavya (Cow therapy). In: National Symposium on Historical Overview on Veterinary Sciences and Animal Husbandry in Ancient India, Vedic and Ashokan Period. IVRI, Izatnagar, April 16-17.

Chauhan, R. S. (2005). Cowpathy: A new version of Ancient Science. Employment News, 30: 9-15.

Crouch, I. J. and van Staden, J. (1993). Evidence for the presence of plant growth regulators in commercial seaweed products. Plant Growth Regul., 13:21-29.

Davey, J. E. and van Staden, J. (1978). Cytokinin activity in Lupinus albus. III. Distribution in fruits. Physiol. Plant, 43:87-93.

Delia, B. R. (2001). A guide to carotenoid analysis in food. OMNI Research. ILSI Human Nutrition Institute One Thomas Circle, N.W. Washington, D. C., USA, pp. 5-10.

de Pádua, M.; Fontoura, P. S. G. and Mathias, A. L. (2004). Chemical composition of Ulvaria oxysperma (Kützing) bliding, Ulva lactuca (Linnaeus) and Ulva fascita(Delile). Braz. arch. biol. technol., 47(1): 49-55.

Duarte, M. E. R.; Cardoso, M. A.; Noseda, M. D. and Cerezo, A. S. (2001). Structural studies on fucoidan from brown seaweed Sagassum stenophyllum. Carbohydrate Res., 333: 281-293.

Durand, N.; Briand, X. and Meyer, C. (2003). The effect of marine bioactive substances (NPRO) and exogenous cytokinins on nitrate reductase activity in Arabidopsis thaliana. Physiol. Plant, 119: 489-493.

El-Sheekh, M. M. and El-Saied, A. E. F. (2000). Effect of crude extract on seed germination, seedling growth and some metabolic processes of Vicia faba L. Cytobios., 101: 23-35.

Featonby-Smith, B. C. and van Staden, J. (1983a). The effect of seaweed concentrate on the growth of tomato plants in nematode-infested soil. Sci. Hortic., 20:137-146.

Featonby-Smith, B. C. and van Staden, J. (1983b). The effect of seaweed concentrate and fertilizer on the growth of Beta vulgaris. $Z$. Pflanzenphysiol., 112:155-162.

Fornes, F. S.; Sanchez-Perales, M. and Guadiola J. L. (2002). Effect of a seaweed extract on the productivity of (de Nules) Clementine Mandarin and Navelina Orange. Botanica Marina, 45: 486-489. 
Francis, X.; Cunningham, J.; Hansel, L. and Elisabeth, G. (2007) Carotenoid Biosynthesis in the Primitive Red Alga Cyanidioschyzon merolae. Eukaryot Cell, 3: 533-545.

Garg, N. and Chauhan, R. S. (2003). Cow therapy as an alternative to antibiotics. Indian Science Congress, Bangalore, pp.3-7.

Goldgur, Y.; Rom, S.; Ghirlando, R.; Shkolnik, D.; Shadrin, N; Konrad, Z. and Bar-Zvi, D. (2007). Desiccation and zinc binding induce transition of tomato abscisic acid stress ripening 1, a Water stress- and salt stressregulated plant-specific protein, from unfolded to folded State. Plant Physiology, 143:617-628.

Guo, W. J.; Meetam, M. and Goldsbrough, P. B. (2008). Examining the specific contributions of individual arabidopsis metallothioneins to copper distribution and metal tolerance1. Plant Physiology, 146:1697-1706.

Hahn, H.; de Zacks, R. and Kende, H. (1974). Cytokinin formation in pea seeds. Naturwissenschaften, 61:170-171.

Hedge, D. M.; Dwivedi, B. S. and Babu, S. N. S. (1999). Biofertilizers for cereal production in India - A review. Indian Journal of Agricultural Sciences, 69(2): 73-83.

Hong, D. D.; Hien, H. M. and Son, P. N. (2007). Seaweeds from Vietnam used for functional food, medicine and biofertilizer. J. Appl. Phycol., 19:817826.

Malaguti, D.; Rombola, A. D.; Gerin, M. and Simoni, G. (2002). Effect of seaweed extracts based leaf sprays on the mineral status and fruit quality of apple. Acta Horticulturae, 594: 357-459.

Nakao, H.; Maeda, T. and Kuwastsuka, S. (1994). Effect of soil amendment of hot water extract of Chorella cells on growth of plants. Japanease J. Soil Science and Plant Nutrition, 65: 670-676.

Nelson, W. R. and van Staden J. (1984). The effect of seaweed concentrate on wheat culms. J. Plant Physiol., 115: 433-437.

Ordog, V.; Stirk, W. A.; van Staden, J; Novak,O. and Strnad, M. (2004). Endogenous cytokinins in the three genera of microalgae from the Chlorophyta. J. Phycol., 40:88-95.

Rayorath, P.; Khan, W.; Palanisamy, R.; MacKinnon, S. L.; Stefanova, R.; Hankins, S. D.; Critchley, A. T. and Prithiviraj, B. (2008). Extracts of the brown seaweed Ascophyllum nodosum induce gibberellic acid (GA3)independent amylase activity in barley. J. Plant Growth Regul.,

Rioux, L. E.; Turgeon, S. L. and Beaulieu, M. (2007). Characterization of polysaccharides extracted from brown seaweeds. Carbohydrate Polym., 69: 530-537.

Rufty, W. T.; Charles, J.; MacKown, T. and Israel, D. W. (1990). Phosphorus stress effects on assimilation of nitrate. Plant Physiology, 94: 328-333. 
Salah El Din, R. A.; Elbakry, A. A.; Ghazi, S. M. and Abdel Hamid. O. M. (2008). Effect of seaweed extract on the growth and yield of Faba bean (Vicia faba L.). Egypt. J. of Phycology, 9: 25-38.

Sanker, V.; Tripathi, P. C.; Qureshi, M. A. A. and Lawanda, K. E. (2001). Effect of organic seaweed extract on growth, yield and quality of onion (Allium cepa). South-India-Horticulture, 49: 247-248.

Saxena, S.; Garg, V. and Chauhan, R. S. (2004). Cow Urine Therapy: Promising cure for human ailments. The Indian Cow, 1:25-30.

Sevilla, F.; Lopez-Gorgé, J. and del Ro, L. A. (1982). Characterization of a manganese superoxide dismutase from the higher Plant Pisum sativum. Plant Physiology, 70:1321-1326.

Smith, F. B. C. and van Staden, J. (1983). The effect of seaweed concentration and fertilizer on the growth of Beta vulgaris. A. pflanzenphysiol, 112:115162.

Stirk, W. A.; Novak, M. S. and van Staden, J. (2003). Cytokinins in macroalgae. Plant Growth Regul., 41:13-24.

Tabe, L. M. and Droux, M. (2002). Limits to sulfur accumulation in transgenic lupin seeds expressing a foreign sulfur-rich protein. Plant Physiology, 128: 1137-1148.

Taiz, L. and Zeiger, E. (2006). Plant Physiology. Benjamin, Cummings Publisher Company, Redwood, California, USA. pp:559.

Thirumaran, G.; Arumugam, M.; Arumugam, R. and Anantharaman, P. (2009). Effect of Seaweed Liquid Fertilizer on Growth and Pigment Concentration of Cyamopsis tetrogonolaba (L) Taub. AmericanEurasian Journal of Agronomy, 2: 50-56.

van Staden, J.; Beckeff, R. P. and Rijkenberg, M. D. (1995). Effect of seaweed concentrate on the growth of the seedlings of three species of Eucalyptus. South African Journal of Botany, 61(4): 169-172.

Vernieri, P.; Borghesi, E.; Ferrante, A. and Magnani, G. (2005). Application of biostimulants in floating system for improving rocket quality. Food Agric. Environ., 3: 86-88.

Vessey, J. K. (2003). Plant growth promoting rhizobacteria as biofertilizers. Plant Soil, 255:571-586.

Vílchez, C.; Forján, E.; Cuaresma, M.; Bédmar, F.; Garbayo, I. and Vega, J. M. (2011) Marine Carotenoids: Biological Functions and Commercial Applications. Mar. Drugs., 9: 319-333.

Zodape, S. T. (2001). Seaweeds as a biofertilizer. Journal of Science and Industrial Research, 60: 378-382. 


\section{استخذامات بعض من الطحالب البحرية المصرية كمخصب ورقى لنبات الفول}

$$
\text { البلاىى البحري }
$$

\section{رضوى أحمد خيرى1, إسلام محمود المناوى2 ومحمد عبد الحميد البرماوى}

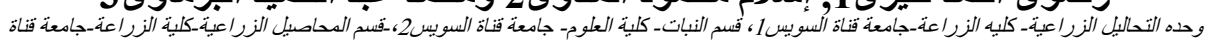

تم تجميع ثلاثه انواع من الطحالب البحريه (الاولفا والانترومورفا والساركونيما) من شاطىى الإيء

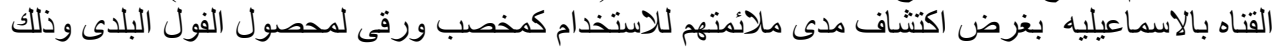

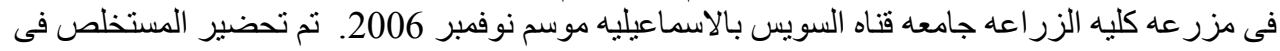

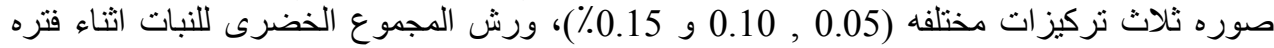

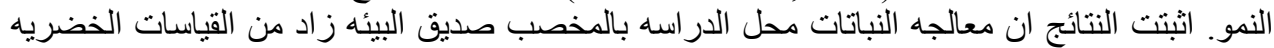

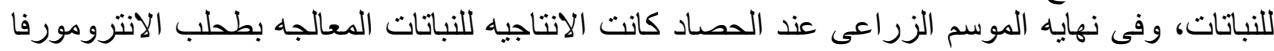

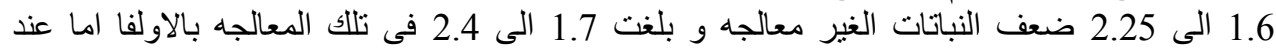

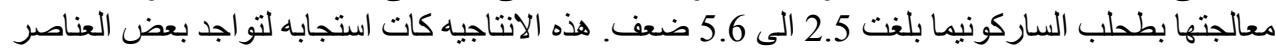

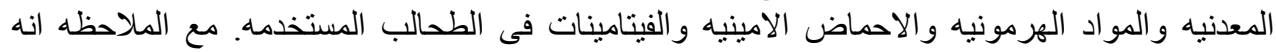

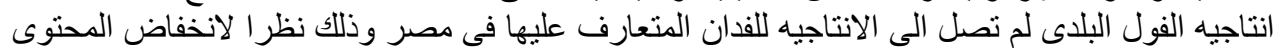

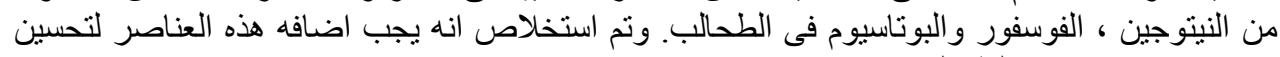
الانتاجيه عند استخدام الطحالب كمخصبات عضورئ الفوريه. 